\title{
Indeks massa tubuh, asupan vitamin D, dan serum 25-hydroxyvitamin D pada pasien kanker payudara
}

\author{
Body mass index, vitamin D intake and serum 25-hydroxyvitamin D in patients with breast cancer
}

\author{
Amilia Yuni Damayanti' ${ }^{1}$ Dono Indarto², Brian Wasita², Tonang Dwi Ardyanto²
}

${ }^{1}$ Program Studi Gizi, Fakultas Ilmu Kesehatan Universitas Darussalam Gontor

${ }^{2}$ Pascasarjana Universitas Sebelas Maret Surakarta

\begin{abstract}
Background: Breast cancer is the most common malignancy in women in the world. Vitamin D helps control the majority of gene expression in female reproductive tissues. Body mass index (BMI) influences the bioavailability of vitamin D. Diet is one of the main sources of vitamin D and it is directly converted into 25-hydroxyvitamin D [25 (OH) D] in the liver. Objective: This study aimed to analyze the relationship between BMI and vitamin D intake and 25 (OH)Dserum in patients with breast cancer. Method: Analytic observational with cross sectional design was used in this study. A total of 37 breast cancer patient visited Dr. Moewardi Hospital in Surakarta was selected as research subjects using a purposive sampling technique. BMI data was obtained by measuring body weight and height. Vitamin D intake was determined using 1 x 24-hour food recall and semi-quantitative food frequency questionnaire. While, 25(OH)D serum was measured using enzyme-linked immunoabsorbent assay. Data analysis used Spearman correlation test. Results: The averages of BMI, vitamin D intake and 25(OH)D serum of breast cancer patients were $21.96 \pm 3.63 \mathrm{~kg} / \mathrm{m}^{2}, 3.50 \pm 3.30 \mu \mathrm{g} /$ day and $16.01 \pm 14.67 \mathrm{ng} / \mathrm{mL}$ respectively. Most breast cancer patients had less vitamin $D$ intake and $25(\mathrm{OH}) D$ serum deficiency. There was a weak relationship between BMI $(r=0188, p=0.266)$ and vitamin $D(r=0.113$, $p=0.507)$ and $25(\mathrm{OH}) D$ serum in breast cancer patients. Conclusion: There were no significant correlations between BMI and vitamin D intake with 25(OH)D serum in breast cancer patients. Further study is required on the effect of chemotherapy regimens on vitamin D metabolism.
\end{abstract}

KEY WORD: BMI; breast cancer; vitamin D intake; $25(\mathrm{OH}) D$ serum

\begin{abstract}
ABSTRAK
Latar belakang: Kanker payudara merupakan jenis kanker yang paling banyak diderita perempuan di dunia. Vitamin D berfungsi mengatur sebagian besar ekspresi gen pada jaringan reproduksi wanita. Indeks massa tubuh (IMT) berpengaruh terhadap bioavaibilitas vitamin D. Salah satu sumber utama vitamin D berasal dari diet, yang akan diubah langsung menjadi serum 25 hydroxyvitamin $D[25(\mathrm{OH}) \mathrm{D}]$ begitu masuk ke organ hati. Tujuan: Menganalisis hubungan antara IMT dan asupan vitamin D dengan serum 25(OH)D pasien kanker payudara. Metode: Penelitian observasional dengan rancangan cross sectional. Sebanyak 37 pasien kanker payudara rawat jalan di Rumah Sakit Dr. Moewardi Surakarta dipilih sebagai subjek penelitian menggunakan teknik purposive sampling. Data IMT diperoleh dengan pengukuran berat badan dan tinggi badan. Asupan vitamin D diperoleh dengan menggunakan metode food recall 1x24 jam dan semi quantitative food frequency questionnaire (SQ-FFQ). Pengujian serum 25(OH)D menggunakan metode enzyme-linked immunoabsorbent assay. Analisis data menggunakan uji statistik korelasi Spearman. Hasil: Rerata IMT subjek penelitian adalah 21,96 $\pm 3,63 \mathrm{~kg} / \mathrm{m}^{2}$, asupan vitamin D 3,50 $\pm 3,30 \mu \mathrm{g}$, dan serum $25(\mathrm{OH})$ D $16,01 \pm 14,67 \mathrm{ng} / \mathrm{mL}$. Hasil ini menunjukkan bahwa sebagian besar subjek memiliki status gizi normal dan serum $25(\mathrm{OH}) \mathrm{D}$ defisit. Semua subjek memiliki asupan vitamin D yang tergolong kurang. Terdapat hubungan yang tergolong lemah antara IMT $(\mathrm{r}=0,188 ; \mathrm{p}=0,266)$ dan asupan vitamin $\mathrm{D}(\mathrm{r}=0,113 ; \mathrm{p}=0,507)$ dengan serum $25(\mathrm{OH}) \mathrm{D}$ pasien kanker payudara. Simpulan: Tidak ada hubungan signifikan antara IMT dan asupan vitamin D dengan serum 25(OH)D pasien kanker payudara. Perlu diteliti lebih lanjut tentang pengaruh regimen kemoterapi terhadap metabolisme vitamin D.
\end{abstract}

KATA KUNCI: IMT; kanker payudara; asupan vitamin D; serum 25(OH)D

Korespondensi: Amilia Yuni Damayanti, Program Studi Ilmu Gizi, Universitas Darussalam Gontor-Kampus Mantingan, Jl. Raya Maospati-Solo, Sambi Rejo, Mantingan, Kec. Ngawi, Jawa Timur 63257, Indonesia, e-mail: amiliayd227@gmail.com 


\section{PENDAHULUAN}

Kanker payudara merupakan jenis kanker yang paling banyak menyebabkan kematian dan paling banyak ditemukan pada wanita di 140 negara dari 184 negara di dunia. Sejak tahun 2008 hingga 2012, pasien kanker payudara meningkat hingga $20 \%$ sedangkan kasus kematian meningkat sebanyak 14\% (1). Jumlah persentase kasus baru tertinggi yaitu sebesar $43,3 \%$ dan persentase kematian akibat kanker payudara sebesar 12,9\% (2). Rata-rata jumlah pasien kanker payudara rawat jalan yang berobat di RSUD Dr. Moewardi Surakarta pada tahun 2014 yaitu 824 pasien dan pada tahun 2015 sebanyak 1093 pasien. Terjadi peningkatan jumlah pasien kanker payudara yang cukup signifikan yaitu sebanyak 33\% (3).

Kanker payudara merupakan keganasan pada jaringan payudara yang dapat berasal dari epitel duktus maupun lobulusnya (4). Salah satu pilihan untuk terapi tambahan bagi pasien kanker payudara adalah kemoterapi. Penelitian meta analisis oleh The Early Breast Cancer Trialists Collaborative Group (EBCTCG) dari 194 unconfounded randomised controlled trials kemoterapi dan terapi hormon, menyimpulkan bahwa terapi tambahan kemoterapi dapat menurunkan 38\% mortalitas pada pasien kanker payudara usia $<50$ tahun dan $20 \%$ usia 50-69 tahun. The Early Breast Cancer Trialists, Collaborative Group dengan jumlah subjek penelitian sebesar 100.000 pasien (meta-analisis), menunjukkan bahwa tambahan kemoterapi dapat menurunkan angka kekambuhan dan meningkatkan harapan hidup pasien kanker (5).

Vitamin D bertugas mengatur sebagian besar ekspresi gen pada jaringan reproduksi wanita karena vitamin ini bersifat antikarsinogenik (6). Vitamin D dapat mencegah angiogenesis dan pembelahan pada sel kanker payudara, sehingga dapat menyebabkan terjadi apoptosis pada sel kanker (7). Indikator standar penentuan kadar vitamin D dalam tubuh adalah serum 25-hydroxyvitamin $D(8)$.

Serum 25(OH)D dapat dipengaruhi oleh indeks massa tubuh (IMT) pasien kanker payudara. Jaringan adiposa pada obesitas dapat mengganggu degradasi dan distribusi vitamin D $(9,10)$. Selain itu, jaringan adiposa yang tebal pada obesitas dapat menghambat penyerapan sinar matahari yang merupakan prekursor vitamin D sehingga berpengaruh secara tidak langsung terhadap serum 25(OH)D (11). Pasien obes (IMT $\geq 30$ $\mathrm{kg} / \mathrm{m}^{2}$ ) cenderung memiliki serum $25(\mathrm{OH}) \mathrm{D}$ lebih rendah dibandingkan dengan pasien non-obes atau dibandingkan dengan pasien yang tergolong normal dan overweight $\left(\mathrm{IMT}<30 \mathrm{~kg} / \mathrm{m}^{2}\right)$. Semakin tinggi IMT maka semakin rendah serum $25(\mathrm{OH}) \mathrm{D}$ (12). Hal ini akan berhubungan dengan stadium kanker payudara dan peningkatan angka mortalitas pada pasien kanker payudara (13).

Asupan makanan sumber vitamin D maupun suplementasi vitamin D berpengaruh terhadap serum $25(\mathrm{OH}) \mathrm{D}$ pada pasien kanker payudara (14). Serum $25(\mathrm{OH}) \mathrm{D}$ dikategorikan defisit $(\leq 50 \mathrm{nmol} / \mathrm{L})$, insufisien (50-72 nmol/L), dan cukup ( $\geq 72 \mathrm{nmol} / \mathrm{L})$ (8). Asupan minimum vitamin D adalah 600 IU setiap harinya (15). Tujuan dari penelitian ini adalah untuk menganalisis hubungan antara IMT dan asupan vitamin D dengan serum 25(OH)D pasien kanker payudara di RS Dr. Moewardi Surakarta.

\section{BAHAN DAN METODE}

Jenis penelitian yang digunakan adalah penelitian deskriptif dengan desain penelitian cross sectional yang dilaksanakan mulai bulan Februari sampai dengan bulan Mei 2016. Penelitian ini dilaksanakan di Poli Bedah Onkologi, Ruang Mawar 3 untuk one day service pasien kemoterapi dan Laboratorium Patologi Klinik Rumah Sakit Umum Daerah (RSUD) Dr. Moewardi Surakarta. Populasi penelitian ini adalah pasien kanker payudara yang menjalani kemoterapi di RSUD Dr. Moewardi Surakarta dengan jumlah sampel penelitian sebanyak 37 pasien. Teknik pengambilan subjek penelitian yang digunakan adalah purposive sampling dan subjek yang diambil memenuhi kriteria inklusi, yaitu stadium kanker payudara I - III setelah menjalani operasi; siklus kemoterapi 3, 4 dan 5; dan berusia 18 - 65 tahun. Sementara itu, kriteria eksklusi yaitu pasien dengan keluhan kehilangan nafsu makan dan mual muntah berat serta pasien dengan komplikasi penyakit kronik seperti gagal jantung, hati, gagal ginjal pre ataupun pos dialisis, dan diabetes mellitus (DM).

Definisi dan klasifikasi variabel yang diteliti, yaitu: 1) Siklus kemoterapi adalah berapa kali pasien telah menerima obat untuk membunuh sel-sel kanker, diberikan 
dalam bentuk infus atau dalam bentuk oral (tablet) $(3,4,5)$ dengan skala data ordinal; 2) Stadium kanker payudara adalah derajat keparahan kondisi pasien berdasarkan tingkat keganasan pada jaringan payudara atau pada tingkat metastasis, data ini didapatkan dari rekam medis pasien (I, II atau III) dengan skala data nominal; 3) Histologi kanker payudara adalah penggolongan kanker payudara berdasarkan carcinoma in situ atau carcinoma invasive/infiltrating, data ini diperoleh dari rekam medis pasien (Carcinoma in situ atau Carcinoma invasive) dengan skala data nominal; 4) Indeks massa tubuh (IMT) adalah indikator status gizi yang merupakan hasil pembagian antara berat badan dalam satuan kilogram dengan tinggi badan dalam satuan meter kuadrat (kg/ $\mathrm{m}^{2}$ ). Alat ukur yang digunakan adalah timbangan injak untuk mengukur berat badan (BB) dan microtoice untuk mengukur tinggi badan (TB) dengan skala data rasio; 5) Asupan vitamin D adalah rerata jumlah asupan makanan dan atau suplemen sumber vitamin D yang dikonsumsi setiap hari. Alat ukur yang digunakan adalah formulir food recall 1x24 jam dan formulir semi-quantitative food frequency questionnaire (SQ-FFQ) yang diolah dengan nutrisurvey dan skala data rasio, untuk pengkategorian asupan vitamin D dikatakan kurang jika $<600 \mathrm{IU} / 15 \mu \mathrm{g}$ dan cukup jika $\geq 600 \mathrm{IU} / 15 \mu \mathrm{g}$; 6) Serum 25(OH)D adalah indikator untuk mengukur kadar vitamin $\mathrm{D}$ dalam darah. Satuan yang digunakan untuk kadar vitamin D dalam darah adalah nanogram per mililiter $(\mathrm{ng} / \mathrm{mL})$ dengan skala data rasio. Alat ukur yang digunakan adalah kit ELISA E 1543.

Bahan penelitian ini adalah $3 \mathrm{ml}$ darah vena dari subjek penelitian yang diambil oleh tenaga medis RSUD Dr. Moewardi Surakarta, kemudian dimasukkan ke tabung vakum berisi gel separator yang berfungsi memisahkan serum dan sel darah, disentrifugasi dan diambil serumnya, kemudian diperiksa kadar serum 25(OH)D menggunakan kit ELISA Human Vitamin D. Pengukuran BB dan TB dilakukan sebanyak satu kali pada saat wawancara.

Uji normalitas data menggunakan KolmogorofSmirnov dan uji hubungan menggunakan analisis korelasi Spearman. Ethical clearence diperoleh dari Komisi Etik RSUD Dr. Moewardi Surakarta. Etika penelitian yaitu sebelum dilakukan pengukuran BB dan TB, wawancara serta pengambilan sampel darah, subjek diberitahu tentang maksud dan tujuan pengumpulan data seta dijelaskan bahwa penelitian bersifat observasi, tidak melakukan tindakan intervensi terhadap subjek penelitian. Semua keterangan, jawaban, dan hasil pemeriksaan darah sematamata untuk kepentingan ilmiah dan dijaga kerahasiannya. Pemeriksaan serum 25(OH)D pada akhir wawancara asupan vitamin $\mathrm{D}$, dengan meminta kesediaan pasien untuk dimintai sampel darah sebanyak $3 \mathrm{ml}$. Sebagai bukti kesediaan menjadi subjek penelitian, responden diminta untuk menandatangani lembar informed consent.

\section{HASIL}

Tabel 1 menunjukkan bahwa semua subjek $(n=37)$ memiliki asupan yang tergolong kurang $(<600$ IU/15 $\mu \mathrm{g})$. Sebagian besar subjek penelitian yang memiliki serum 25(OH)D defisit adalah usia dewasa, menjalani siklus kemoterapi 3, stadium III, postmenopause, status gizi normal dan asupan tergolong kurang. Sedangkan semua subjek yang memiliki serum $25(\mathrm{OH}) \mathrm{D}$ insufisien merupakan subjek dengan usia lanjut, menjalani siklus kemoterapi 4, stadium II dan memiliki status gizi normal.

Hasil analisis deskriptif pada Tabel 2 menunjukkan bahwa rerata usia subjek penelitian adalah 46,35 $\pm 8,40$ tahun; IMT sebesar $21,96 \pm 3,63 \mathrm{~kg} / \mathrm{m}^{2}$; asupan vitamin D

\section{Tabel 1. Distribusi karakteristik subjek penelitian}

\begin{tabular}{lcc}
\hline \multicolumn{1}{c}{ Karakteristik subjek } & $\mathbf{n}$ & $\mathbf{\%}$ \\
\hline Usia (tahun) & & \\
$\quad 25-50$ & 26 & 70,27 \\
$\quad>51$ & 11 & 29,73 \\
Siklus kemoterapi & & \\
3 & 16 & 43,24 \\
4 & 13 & 35,14 \\
5 & 8 & 21,62 \\
Stadium & & \\
II & 12 & 32,43 \\
III & 25 & 67,57 \\
IMT (kg/m ${ }^{2}$ ) & & \\
$\quad<17,0$ & 1 & 2,70 \\
$17,0-18,4$ & 1 & 2,70 \\
$18,5-25$ & 30 & 81,08 \\
$25,1-27,0$ & 2 & 5,41 \\
$\quad>27,0$ & 3 & 8,11 \\
Asupan vitamin D & & \\
$\quad<600 \mathrm{IU} / 15 \mu \mathrm{g}$ & 37 & 100,00 \\
$\quad \geq 600 \mathrm{IU} / 15 \mu \mathrm{g}$ & 0 & 0 \\
\hline
\end{tabular}


Tabel 2. Analisis deskriptif variabel penelitian

\begin{tabular}{lcccc}
\hline \multicolumn{1}{c}{ Variabel } & $\mathrm{n}$ & Min & Maks & Rerata \pm SD \\
\hline Usia $($ tahun $)$ & 37 & 30,00 & 59,00 & $46,35 \pm 8,40$ \\
IMT $\left(\mathrm{kg} / \mathrm{m}^{2}\right)$ & 37 & 14,40 & 32,40 & $21,96 \pm 3,63$ \\
Asupan vitamin D $(\mu \mathrm{g})$ & 37 & 0,10 & 13,80 & $3,50 \pm 3,30$ \\
Serum $25(\mathrm{OH}) \mathrm{D}(\mathrm{ng} / \mathrm{mL})$ & 37 & 4,50 & 69,70 & $16,01 \pm 14,67$ \\
\hline
\end{tabular}

Tabel 3. Analisis bivariat hubungan usia, IMT, dan asupan vitamin D dengan serum 25(OH)D

\begin{tabular}{lcc}
\hline \multirow{2}{*}{ Variabel } & \multicolumn{2}{c}{ Serum 25(OH)D } \\
\cline { 2 - 3 } & $\mathbf{r}$ & $\mathbf{p}$ \\
\hline Usia & 0,335 & $0,043^{*}$ \\
IMT & 0,188 & 0,266 \\
Asupan vitamin D & 0,113 & 0,507 \\
\hline
\end{tabular}

*bermakna $(\mathrm{p}<0,05)$; Uji statistik korelasi Spearman

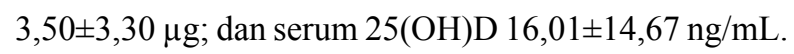
Nilai SD variabel asupan vitamin D dan serum $25(\mathrm{OH}) \mathrm{D}$ masih terlalu lebar, mendekati nilai rerata.

Hasil uji statistik pada Tabel 3 menunjukkan bahwa ada hubungan yang signifikan antara usia dengan serum $25(\mathrm{OH}) \mathrm{D}$. Namun, tidak terdapat hubungan yang signifikan antara IMT $(\mathrm{p}=0,266)$ dan asupan vitamin $\mathrm{D}$ $(\mathrm{p}=0,507)$ dengan serum $25(\mathrm{OH}) \mathrm{D}$. Koefisien korelasi usia adalah 0,335 maka kekuatan hubungan tergolong cukup atau sedang sedangkan koefisien korelasi IMT $(0,188)$ dan asupan vitamin $\mathrm{D}(0,113)$, maka kekuatan hubungan sangat lemah dan ketiga korelasi yaitu usia, IMT, dan asupan vitamin D bernilai positif. Hal ini menunjukkan bahwa peningkatan usia, IMT, dan asupan vitamin $\mathrm{D}$ akan diikuti peningkatan kadar serum $25(\mathrm{OH})$ D.

Hasil SQ-FFQ menunjukkan bahwa rerata pola konsumsi makanan pokok subjek penelitian adalah nasi 2-3 kali/hari (100-200g/porsi). Selain nasi mereka juga mengkonsumsi singkong, kentang, roti dan biskuit. Lauk nabati yang paling banyak dikonsumsi yaitu tahu dan tempe 1-3 potong sedang/hari (25-50 gr/ porsi). Akan tetapi, konsumsi lauk hewani baik dari bahan makanan alami maupun makanan atau minuman yang sudah difortifikasi vitamin $\mathrm{D}$ tergolong kurang dan tidak beragam. Rata-rata subjek hanya mengkonsumsi telur ayam 2-4 kali/minggu (60 g/porsi) dan daging ayam 1 kali/minggu sedangkan daging sapi dan ikan baik ikan air tawar (seperti patin, lele, nila) atau ikan laut (salmon, makarel, sarden, udang, cumi, tuna) jarang sekali dikonsumsi. Mayoritas subjek juga jarang mengkonsumsi susu. Subjek penelitian tidak mengkonsumsi makanan yang difortifikasi atau diperkaya vitamin D (susu, jus jeruk kemasan, yoghurt, dan margarin). Hanya 2 subjek yang mengkonsumsi suplemen makanan (CDR) 1 kali/ hari yang mengandung vitamin D (400 IU) sedangkan suplemen penambah nafsu makan $3 \mathrm{kali} / \mathrm{hari}$ (Curcuma Plus) yang mengandung vitamin D 100 IU hanya 2 subjek.

\section{BAHASAN}

Semua subjek penelitian ini adalah perempuan dengan histologi carcinoma invasive dan memiliki asupan vitamin D yang tergolong kurang. Berdasarkan hasil penilaian pola makan dengan $S Q-F F Q$, rendahnya asupan bahan makanan sumber vitamin D subjek penelitian kanker payudara rawat jalan di RSUD Dr. Moewardi dapat disebabkan karena kepercayaan atau mitos jawa. Berdasarkan hasil wawancara, subjek menyatakan memiliki kepercayaan bahwa makanan "amis-amisan" yang berasal dari daging, telur, ikan, dan susu serta produk olahannya yang juga merupakan sumber utama vitamin D justru akan memperparah kondisi bekas luka operasi kanker payudara. Hal ini timbul karena keluhan rasa gatal yang mereka keluhkan jika banyak mengkonsumsi "amisamisan" tersebut sehingga mereka hanya mengkonsumsi sumber bahan makanan nabati.

Hasil analisis menunjukkan tidak bermaknanya hubungan antara IMT dan asupan vitamin D dengan serum $25(\mathrm{OH}) \mathrm{D}$ pasien kanker payudara. Sementara itu, variabel usia menunjukkan hubungan yang bermakna $(\mathrm{p}=0,046)$ dengan serum $25(\mathrm{OH}) \mathrm{D}$, dengan kekuatan hubungan yang tergolong cukup atau sedang $(\mathrm{r}=0,335)$. Semakin bertambahnya usia akan meningkatkan kemampuan kulit untuk memproduksi vitamin D3 yang selanjutnya akan diubah menjadi vitamin $\mathrm{D}$, kemudian oleh sitokrom P450 R21 di organ hati akan langsung diubah menjadi serum 25(OH)D dengan bantuan enzim 25 hydroxylase CYP27A1 $(16,17)$.

Pada penelitian ini ditemukan adanya hubungan antara IMT dengan serum $25(\mathrm{OH}) \mathrm{D}$, walaupun secara statistik tidak bermakna. Hasil ini didukung oleh 
penelitian sebelumnya yang menyatakan adanya hubungan yang lemah antara IMT dengan kenaikan serum 25(OH)D pada pasien kanker dan serum 25(OH) D yang rendah pada pasien obes atau gemuk (18). Orang obes atau gemuk cenderung memiliki serum $25(\mathrm{OH}) \mathrm{D}$ defisit. Lemak akan menurunkan bioavaibilitas vitamin D sebanyak $57 \%$ pada bagian tubuh yang mengalami penimbunan lemak pada obesitas karena sifat vitamin D yang larut lemak (19) dan menurunkan sintesis $25(\mathrm{OH})$ D di dalam hati dengan meningkatkan level $1,25(\mathrm{OH})_{2} \mathrm{D}$. Hal ini berpengaruh terhadap serum 25(OH)D (20).

Namun, hasil ini berbeda dengan penelitian yang menyebutkan bahwa tidak ada hubungan antara IMT dengan serum 25(OH)D. Perbedaan ini terletak pada alat ukur serum $25(\mathrm{OH}) \mathrm{D}$, penelitian tersebut menggunakan high performance liquid chromatography (HPLC) yang memiliki ketelitian dan keakuratan hasil lebih baik dibandingkan dengan metode ELISA. Selain itu, penelitian tersebut menggunakan rancangan kasus kontrol pada pasien kanker payudara yang baru didiagnosis kanker payudara dan belum menjalani kemoterapi sehingga kemungkinan tidak ada perbedaan maupun hubungan dengan serum 25(OH)D (21). Sementara itu, pada penelitian ini menggunakan rancangan cross sectional pada pasien kanker payudara stadium II dan III yang menjalani kemoterapi. Efek samping pengobatan (termasuk kemoterapi) kanker payudara dapat menyebabkan penurunan serum $25(\mathrm{OH}) \mathrm{D}$ pada pasien. Hal ini dikarenakan setelah mendapatkan pengobatan kanker payudara, pasien cenderung mengalami perubahan pola makan hingga setelah kemoterapi. Paparan sinar matahari dan suplementasi ( $\geq 400 \mathrm{IU})$, baik sebelum maupun sesudah menjalani pengobatan dapat memperbaiki serum 25(OH)D (22).

Hasil analisis penelitian ini menunjukkan adanya arah korelasi yang positif antara IMT dan serum $25(\mathrm{OH})$ $\mathrm{D}$, artinya setiap kenaikan IMT akan diikuti dengan kenaikan serum 25(OH)D. Namun, penelitian lain menyatakan bahwa semakin tinggi IMT maka semakin rendah serum 25(OH)D. Penelitian tersebut memasukkan pasien yang baru didiagnosis kanker payudara sebagai subjek penelitian dengan rerata pasien memiliki status gizi yang berbeda yaitu status gizi normal $(32,4 \%)$, overweight $(33,7 \%)$ dan obes $(30,8 \%)$. Selain itu, metode pengukuran serum 25(OH)D yang digunakan pada penelitian tersebut adalah radioimmunoassay (RIA) yang lebih akurat dibandingkan metode ELISA(23). Sementara pada penelitian ini, sebagian besar subjek penelitian memiliki status gizi normal $(81,1 \%)$ dengan serum $25(\mathrm{OH})$ D sebagian besar $(91,9 \%)$ tergolong defisit $(<30$ $\mathrm{ng} / \mathrm{mL}$ ). Namun demikian, semua subjek penelitian yang tidak memiliki status gizi normal (gemuk) juga memiliki serum 25(OH)D yang tergolong defisit.

Mekanisme hubungan IMT terutama overweight dan obes dengan kanker payudara melibatkan tiga sistem hormon, yaitu: 1) Hormon insulin dan Insulin-like Growth Factors (IGFs), terutama IGF binding protein-1 factor (IGF-1). Obesitas berhubungan dengan resistensi insulin. Upaya kompensasi saat terjadi kelebihan glukosa bebas, maka pankreas akan meningkatkan konsentrasi insulin. Peningkatan glukosa bebas akan membantu perkembangan tumor dan glukosa akan digunakan sel tumor untuk melakukan proliferasi (24);2) Hormon seks. Obesitas mempengaruhi kanker payudara melalui mekanisme peningkatan sirkulasi beberapa hormon steroid seks, termasuk estrogen, total estradiol, testoteron, dan menurunkan konsentrasi sex hormone binding globulin (SHBG). Hal ini menyebabkan hasil metabolisme yang bersifat karsinogenik meningkat (25). 3) Hormon adipokin (adiponektin, leptin, interleukin, dan resistin) yang diproduksi oleh adiposit dan jaringan adiposa. Orang yang kelebihan berat badan, sel lemak dapat mengganggu pengeluaran adipokinektin sehingga mengganggu fungsi utama adiponektin dan leptin, interleukin dan resistin sebagai anti inflamasi dan anti proliferasi (26).

Hasil penelitian ini menunjukkan bahwa ada hubungan antara asupan vitamin $\mathrm{D}$ dengan serum $25(\mathrm{OH})$ D dengan kekuatan hubungan tergolong lemah. Asupan makanan sumber vitamin D maupun suplementasi vitamin D berhubungan dan berpengaruh terhadap serum 25(OH)D pada pasien kanker payudara karena vitamin $D$ berfungsi untuk mengatur sebagian besar ekspresi gen pada jaringan reproduksi wanita $(14,27,28)$. Selain itu, vitamin ini bersifat antikarsinogenik (6). Vitamin D dapat mencegah angiogenesis dan pembelahan pada sel kanker payudara, sehingga dapat menyebabkan terjadi apoptosis sel kanker $(7,29,30)$. 
Sindrom dispepsia atau perasaan tidak enak pada perut bagian atas yang bisa disertai dengan rasa mual pada pasien kanker setelah menjalani kemoterapi akan menurunkan asupan makan termasuk vitamin D. Pada penelitian ini, sindrom dispepsia disertai dengan rasa mual pada pasien kanker setelah menjalani kemoterapi hanya terjadi pada 1-7 hari sedangkan penelitian dilakukan pada minggu ke-3 setelah kemoterapi sehingga tidak ada keluhan kehilangan nafsu makan berat akibat mual muntah (31).

Faktor lain yang dapat mempengaruhi serum $25(\mathrm{OH}) \mathrm{D}$ selain IMT dan asupan vitamin D pasien kanker payudara adalah asupan kalsium, hormonal, dan lingkungan hidup. Vitamin D berperan terhadap mineralisasi tulang, jika asupan kalsium rendah maka metabolisme vitamin D juga akan terganggu yang dapat berakibat menurunnya serum $25(\mathrm{OH}) \mathrm{D}(32)$. Selain itu, serum 25(OH)D dapat dipengaruhi oleh produksi vitamin D dari kulit yang kurang (33) dan menurunnya kemampuan organ pencernaan (34). Serum 25(OH)D juga dapat dipengaruhi oleh kemampuan absorpsi sistem pencernaan, seperti usus, pankreas, dan empedu. Jika salah satu organ pencernaan terjadi gangguan terutama yang berhubungan dengan pencernaan lemak, maka penyerapan vitamin D juga terganggu, bahkan akan terjadi penurunan hingga 50\% dari total asupan (33).

Reseptor vitamin D atau VDR merupakan hasil dari ikatan retinoid $X$ reseptor (RXR) dengan ligand ( 9 cis-retinoic acid). VDR memiliki pengaruh terhadap perkembangan sel kanker payudara melalui dua jalur, yaitu genomik dan non-genomik. Jalur genomik dimulai ketika 1,25(OH)2D atau calcitriol berikatan dengan VDR yang kemudian masuk ke dalam rangkaian nukleotida vitamin D response element (VDREs), selanjutnya akan menyebabkan transkripsi gen oleh vitamin D. Mekanisme genomik ini terjadi di dalam nukleus atau inti sel sedangkan non-genomik terjadi di membran plasma (35). Mekanisme non-genomik berawal dari interaksi antara 1,25(OH)2D dengan VDR yang berada di caveola membran plasma. Selain itu, 1,25(OH)2D juga berinteraksi langsung dengan reseptor $1,25(\mathrm{OH}) 2 \mathrm{D}$ yang disebut 1,25D3-MARRS (membrane-associated rapid response steroid-binding). Ikatan ini akan mengaktifkan satu atau lebih second messenger systems, termasuk diantaranya phospholipase $C$ (PKC), protein kinase $C$, $G$ protein-coupled receptors, dan phosphatidylinositol3-kinase (PI3K). Hal ini akan mengaktifkan second messengers, terutama $R A F / M A P K$ yang selanjutnya akan mengatur proses sebuah cross-talk dengan inti sel untuk bersama mengatur transkripsi gen (36).

Defisiensi vitamin D dapat menyebabkan kematian dini pada pasien kanker payudara (37). Beberapa penyakit kronik juga berhubungan dengan rendahnya kadar serum 25(OH)D yang memperburuk prognosis pasien kanker payudara. Penyakit kronik yang berpengaruh terhadap serum 25(OH)D diantaranya gagal jantung, hati, gagal ginjal pre ataupun pos dialisis dan diabetes mellitus (DM) (38-40).

Hasil penelitian ini tidak menemukan adanya hubungan bermakna antara BMI dan asupan vitamin $\mathrm{D}$ dengan serum 25(OH)D. Hal ini membuktikan bahwa walaupun sampel berjumlah 37 pasien, tetapi dapat memberikan hasil yang sama dengan penelitian pendukung lain yang memiliki jumlah sampel besar lebih dari 200 pasien. Ketidakbermaknaan dalam hasil analisis statistik dapat diperbaiki dengan penambahan jumlah subjek penelitian. Semakin banyak subjek maka diharapkan akan semakin kecil peluang adanya by chance sehingga peluang adanya hubungan yang bermakna atau signifikan semakin besar.

\section{SIMPULAN DAN SARAN}

Tidak ditemukan hubungan bermakna antara IMT dan asupan vitamin D dengan serum $25(\mathrm{OH}) \mathrm{D}$ pada pasien kanker payudara. Disarankan untuk pasien kanker payudara agar meningkatkan asupan vitamin D lewat makanan atau suplemen dan mempertahankan IMT normal supaya kadar serum 25(OH)D meningkat. Perlu diteliti lebih lanjut tentang pengaruh regimen kemoterapi terhadap metabolisme vitamin D. Diharapkan jumlah sampel dapat ditambah pada penelitian selanjutnya agar peluang adanya hubungan yang bermakna atau signifikan semakin besar.

\section{Pernyataan konflik kepentingan}

Tidak ada konflik kepentingan dalam penelitian ini. 


\section{RUJUKAN}

1. World Health Organization (WHO). Latest world cancer statistics global cancer burden rises to 14.1 million new cases in 2012: Marked increase in breast cancers must be addressed. [series online] 2012 [cited 2016 Jan 25]. Available from: URL: https://www.iarc.fr/en/media-centre/ pr/2013/pdfs/pr223_E.pdf

2. Kementerian Kesehatan Republik Indonesia (Kemenkes RI). Pusat data dan informasi (infodatin). [series online] 2015 [cited 2016 Jan 25]. Available from: URL: http:// www.depkes.go.id>infodatin-kanker

3. Rekam Medik RSUD Dr. Moewardi Surakarta. Data pasien kanker payudara rawat jalan tahun 2014-2015. Surakarta: RSUD Dr. Moewardi; 2015.

4. Kementerian Kesehatan Republik Indonesia (Kemenkes RI). Panduan nasional penanganan kanker nasional "kanker payudara”. Komite Penanggulangan Kanker Nasional. [series online] 2015 [cited 2016 Jan 25]. Available from: URL: http://www.depkes.go.id>kanker-payudara.

5. Peto R, Davies C, Godwin J, Gray R, Pan HC, et al. Comparisons between different polychemotherapy regimens for early breast cancer: meta-analyses of longterm outcome among 100,000 women in 123 randomised trials. Lancet 2012;379(9814):432-44.

6. Shao T, Klein P, Grossbard ML. Vitamin D and breast cancer. Oncologist 2012;17(1):36-45.

7. Krishnan AV, Swami S, Feldman D. The potential therapeutic benefits of vitamin D in the treatment of estrogen receptor positive breast cancer. Steroids 2012;77(11):1107-12.

8. Hollis BW. Circulating 25-hydroxyvitamin D levels indicative of vitamin D sufficiency: implications for establishing a new effective dietary intake recommendation for vitamin D. J Nutr 2005;135(2):317-22.

9. Jorde R, Sneve M, Emaus N, Figenschau Y, Grimnes G. Cross-sectional and longitudinal relation between serum 25-hydroxyvitamin D and body mass index: the Tromso study. Eur J of Nutr 2010;49(7):401-7.

10. Drincic AT, Armas LA, Van Diest EE, Heaney RP. Volumetric dilution, rather than sequestration best explains the low vitamin D status of obesity. Obesity 2012;20(7):1444-8.

11. Wortsman J, Matsuoka LY, Chen TC, Lu Z, Holick MF. Decreased bioavailability of vitamin D in obesity. Am J Clin Nutr 2000;72(3):690-3.

12. Vashi P, Lammersfeld CA, Braun DP, Gupta D. Serum 25-hydroxyvitamin $\mathrm{D}$ is inversely associated with body mass index in cancer. J Nutr 2011;1(10):51.

13. Jacobs ET, Thomson CA, Flatt SW, Newman VA, Rock CL, Pierce JP. Correlates of 25-hydroxyvitamin D and breast cancer stage in the women's healthy eating and living study. Nutr Cancer 2013;65(2):188-94.
14. Shirazi L, Almquist M, Malm J, Wirfält E, Manjer J. Determinants of serum levels of vitamin D: a study of lifestyle, menopausal status, dietary intake, serum calcium, and PTH. BMC Women's Health 2013;1(13):33.

15. Departemen Kesehatan Republik Indonesia (Depkes RI). Peraturan Menteri Kesehatan Republik Indonesia nomor 75 tahun 2013 tentang angka kecukupan gizi yang dianjurkan bagi Bangsa Indonesia. [series online] 2013 [cited 2016 Jan 25]. Available from: URL: http://gizi.depkes.go.id/ download/Kebijakan\%20Gizi/PMK\%2075-2013.pdf.

16. Moan J, Lagunova Z, Lindberg FA, Porojnicu AC. Seasonal variation of 1,25-dihydroxyvitamin $\mathrm{D}$ and its association with body mass index and age. J Steroid Biochem Mol Biol 2009;113(3-5):217-21.

17. Vuolo L, Somma CD, Faggiano A, Colao A. Vitamin D and cancer. Front Endocrinol 2012;3(1):58.

18. Morton ML, Thompson CL. Decreasing 25-hydroxyvitamin D levels account for portion of the effect of increasing body mass index on breast cancer mortality. Mol Nutr Food Res 2013;57(2):260-6.

19. Vilarrasa N, Maravall J, Estepa A, Sanchez R, Masdevall C, Navarro MA, et al. Low 25-hydroxyvitamin D concentrations in obese women: their clinical significance and relationship with anthropometric and body composition variables. J Endocrinol Invest 2007;30(8):653-8.

20. Yildizhan R, Kurdoglu M, Adali E, Kolusari A, Yildizhan B, Sahin HG, et al. Serum 25-hydroxyvitamin D concentrations in obese and non-obese women with polycystic ovary syndrome. Arch Gynecol Obstet 2009;280(4):559-63.

21. Yousef FM, Jacobs ET, Kang PT, Hakim IA, Going $\mathrm{S}$, Yousef JM, et al. Vitamin D status and breast cancer in saudi arabian women: case control study. Am J Clin Nutr 2013;98(1):105-10.

22. Alco G, Igdem S, Dincer M, Ozmen V, Saglam S, Selamoglu D, et al. Vitamin D levels in patients with breast cancer: importance of dressing style. Asian Pac J Cancer Prev 2014;15(3):1357-62.

23. Vashi PG, Lammersfeld CA, Braun DP, Gupta D. Serum 25-hydroxyvitamin D is inversely associated with body mass index in cancer. Nutr J 2011;10(1):51.

24. La Vecchia C, Giordano SH, Hortobagyi GN, Chabner B. Overweight, obesity, diabetes, and risk of breast cancer: interlocking pieces of the puzzle. Oncologist 2011;16(6):726-9.

25. Kaaks R, Berrino F, Key T, Rinaldi S, Dossus L, Biessy $\mathrm{C}$, et al. Serum sex steroids in premenopausal women and breast cancer risk within the European prospective investigation into cancer and nutrition (EPIC). J Natl Cancer Inst 2005;97(10):755-65.

26. Jarde T, Perrier S, Vasson MP, Caldefie-Cheze F. Molecular mechanisms of leptin and adiponectin in breast cancer. Eur J Cancer 2011;47(1):33-43. 
27. Kruger MC, Schollum LM, Kuhn-Sherlock B, Hestiantoro A, Wijanto P, Li-Yu J, et al. The effect of a fortified milk drink on vitamin $\mathrm{D}$ status and bone turnover in post-menopausal women from South East Asia. Bone 2010;46(3):759-67.

28. Dinizulu T, Griffin D, Carey J, Mulkerrin E. Vitamin D supplementation versus combined calcium and vitamin $\mathrm{D}$ in older female patients - an observational study. J Nutr Health Aging 2011;15(8):605-8.

29. Lopes N, Paredes J, Costa JL, Ylstra B, Schmitt F. Vitamin $\mathrm{D}$ and the mammary gland: a review on its role in normal development and breast cancer. Breast Cancer Res 2012;14(3):211.

30. Mohr SB, Gorham ED, Alcaraz JE, Kane CI, Macera CA, Parsons JK, et al. Does the evidence for an inverse relationship between serum vitamin $\mathrm{D}$ status and breast cancer risk satisfy the Hill criteria?. Dermatoendocrinol 2012;4(2):152-7.

31. Rulianti MR, Almasdy D, Murni AW. Hubungan depresi dan sindrom dispepsia pada pasien penderita keganasan yang menjalani kemoterapi di RSUP Dr. M. Djamil Padang. Jurnal Kesehatan Andalas 2013;2(3);137-40.

32. Bidgoli SA, Azarshab H. Role of vitamin D deficiency and lack of sun exposure in the incidence of premenopausal breast cancer: a case control study in Sabzevar, Iran. Asian Pac J Cancer Prev 2014;15(8):3391-6.

33. Tsiaras WG, Weinstock MA. Factors influencing vitamin D status. Acta Derm Venereol 2011;91(2):115-24.
34. Bhutto A, Morley JE. The clinical significance of gastrointestinal changes with aging. Curr Opin Clin Nutr Metab Care 2008;11(5):651-60.

35. Deeb KK, Trump DL, Johnson CS. Vitamin D signalling pathways in cancer: potential for anti cancer therapeutics. Nature 2007;7(1):684-700.

36. Norman AW. Minireview: vitamin D receptor: new assignments for an already busy receptor. Endocrinology 2006;147(12):5542-8.

37. Garland CF, Garland FC, Gorham ED, Lipkin M, Newmark $\mathrm{H}$, Mohr SB, et al. The role of vitamin D in cancer prevention. Am J Public Health 2006;96(2):252-61.

38. Ko BJ, Kim YS, Kim SG, Park JH, Lee SH, Jeong SW, et al. Relationship between 25-hydroxyvitamin D levels and liver fibrosis as assessed by transient elastography in patients with chronic liver disease. Gut Liver 2016;10(5):818-25.

39. Ko EJ, Kim BH, Jeong HY, Soe SU, Yang DH, Lee SY. Serum 25-hydroxyvitamin D as a predictor of hospitalization-free survival in predialysis and dialysis patients with chronic kidney disease: a single-center prospective observational analysis. Kidney Res Clin Pract 2016;35(1):22-8.

40. Klaus KW, Rowena B, John G, Maria F, Paton HA, Jamil $\mathrm{JE}$, et al. Effects of vitamin D on cardiac function in patients with chronic hf: the Vindicate study. J Am Coll Cardiol 2016;67(22):2593-603. 